\title{
PENGARUH LOKASI DAN PELAYANAN TERHADAP KEPUASAN MAHASISWA
}

\author{
Agus Jamaludin \\ Program Studi Pendidikan Ekonomi \\ Universitas Indraprasta PGRI \\ Email: Agus_jamaludin63@yahoo.co.id
}

\begin{abstract}
This study aims to determine how the influence of location and service for student satisfaction in STMIK Institution Indonesia.Dasar theory diapakai by Swastha, the location is temapat where a business or business activity conducted, while Loina (2001.138): Service is an overall process of the establishment of good corporate image melaluoi news media, shaping corporate culture internally, and had a conversation about the company's view to the government leaders and other interested public. The method used reserch Field (field survey) by distributing questionnaires to students as much as 30 orang.Ternyata a magnitude $-87.7, b 2=1.5$, and $b 3=2.1, F$ count $=17.87, F$ table ( $0.05,2,27)=3.58$, the $F=17.87>3.58$, the regression equation is $X 1=-87.7+1.5+2.1 X 2 X 3$, meaningful or significant can be used multiple regression to predict, the population studied. $r 2(3)=$ 0.97, = 106.1 SB2, SB3 = 145.87, $t$ distribusinormal same campus locations with $t$ service to students is $0.01,0.01<1.314, t<t$ tables means no influence location and service to customer satisfaction.
\end{abstract}

Keywords: location and service for student satisfied

\begin{abstract}
ABSTRAK
Penelitian ini bertujuan untuk mengetahui bagaimana pengaruh lokasi dan pelayanan terhadap kepuasan mahasiswa di STMIK Pranata Indonesia .Dasar teori yang diapakai menurut Swastha, lokasi adalah tempat dimana suatu usaha atau aktivitas usaha dilakukan,sedangkan Loina(2001,138): Pelayanan merupakan suatu proses secara keseluruhan dari pembentukan citra perusahaan baik melalui media berita ,membentuk budaya perusahaan secara internal, maupun melakukan komunikasi tentang pandangan perusahaan kepada pemimpin pemerintahan serta publik lainnya yang berkepentingan. Metode penelitian yang digunakan Field reserch(survey lapangan) dengan menyebarkan angket kepada mahasiswa sebanyak 30 orang. Ternyata a besarnya $-87,7, \mathrm{~b} 2=1,5$, dan $\mathrm{b} 3=2,1, \mathrm{~F}$ hitung $=17,87, \mathrm{~F}$ tabel $(0,05,2,27)=3,58$ maka $\mathrm{F}=17,87>3,58$, maka persamaan regresinya yaitu $\mathrm{X} 1=-87,7+1,5 \mathrm{X} 2+2,1 \mathrm{X} 3$, secara berarti atau signifikan dapat digunakan untuk meramal regresi multiple,populasi yang diteliti. $\mathrm{r} 2(3)=0,97, \mathrm{Sb} 2=106,1, \quad \mathrm{Sb} 3=145,87, \mathrm{t}$ hitung distribusi normal lokasi kampus sama dengan t hitung pelayanan terhadap mahasiswa yaitu $0,01,0,01$ $<1,314$, $\mathrm{t}$ hitung $<\mathrm{t}$ tabel yang berarti tidak ada pengaruh lokasi dan pelayanan terhadap kepuasan pelanggan.
\end{abstract}

Kata kunci : Lokasi dan pelayanan terhadap kepuasan mahasiswa. 


\section{PENDAHULUAN}

Dalam era globalisasi ini perkembangan tehnologi dan informasi sangat maju dimana perbedaan jarak dan waktu semakin sempit,dimana kejadian di suatu daerah dapat diakses ditempat lain pada waktu yang sama.Jarak tempuh dari suatu tempat ke tempat lain dengan cepat dan mudah dijangkau, pagi di Jakarta, siang di Surabaya dan malam di Bali.Demikian pula komunikasi dan informasi setiap detik mendapatkan berita dari berbagai macam media,baik media cetak maupun media elektronik. Perkembangan masyarakat tentang media internet sudah menjadi kebutuhan. Sehingga menjadi pangsa pasar bagi orang yang membuka jasa internet kerumah rumah,perkembangan semacam ini semua layanan banyak yang sudah on line dan real time.

Maka peranan komputer,laptop ,HP sangat diperlukan sebagai media perkembangan komunikasi dan informasi.Tentu banyak masyarakat ingin mengetahui dan mempelajari ilmu dibidang tehnologi komunikasi dan informasi ,maka banyak sekolah-sekolah maupun perguruan tinggi yang membuka jurusan komunikasi dan informasi, salah satunya adalah STMIK Pranata Indonesia Bekasi.

STMIK Pranata Indonesia Bekasi membuka program dan jurusan Manajemen Informatika, Komputer Akuntansi, Sistem Informasi,Tehnik Informatika. STMIK Pranata Indonesia berlokasi di depan terminal bus Bekasi yang sangat strategis sehingga mudah dijangkau, mudah dilihat dan dikunjungi , maka banyaklah orang yang ingin kuliah di STMIK Pranata Indonesia, sehingga dari tahun ke tahun jumlah mahasiswanya meningkat.

Seiring jumlah mahasiswanya meningkat membutuhkan gedung yang representatip dan memadai, maka STMIK Pranata Indonesia membuka cabang-cabang yaitu Pondok Gede, Cikarang,Kerawang dan lain-lain. Tentu hal ini untuk memberikan kemudahan mahasiswa untuk kuliah di tempat yang terdekat dengan rumahnya.
Selain dari segi letak lokasi kampus,calon mahasiswa memperhatikan faktor-faktor lain untuk kuliah di perguruan tinggi diantaranya:biaya kuliah yang terjangkau, kualitas dosen, sarana dan prasarana, perpustakaan akriditasi dan pelayanan kepada mahasiswa.

Tetapi seiring dengan waktu berjalan tantangan tetap ada diantaranya faktor internal dan external yang ada, masalahnya sering gonta-ganti kepengurusan,sering telatnya mahasiswa membayar iuran perkuliahan, sarana dan prasarana yang kurang memadai, rasio dosen yang S2, masih sedikit,akriditasi perguruan Tinggi,dan pelayanan kepada mahasiswa, dan lainnya.Juga faktor ekternal yaitu semakin banyaknya persaingan perguruan tinggi swasta lain yang membuka di wilayah Bekasi,juga perguruan Tinggi Negeri yang membuka kesempatan yang sebanyakbanyaknya untuk mendapatkan mahasiswa baru.

Untuk itu penulis mencoba meneliti tentang: Pengaruh lokasi dan pelayanan terhadap kepuasan Mahasiswa di STMIK Pranata Indonesia Bekasi.

Perumusan Masalah "Apakah ada pengaruh lokasi dan pelayanan terhadap kepuasan Mahasiswa di STMIK Pranata Indonesia Bekasi ?

\section{Pengertian lokasi kampus}

Menurut Swastha, lokasi adalah tempat dimana suatu usaha atau aktivitas usaha dilakukan. Sedangkan menurut Kotler : Salah satu kunci menuju sukses adalah lokasi,lokasi dimulai dengan memilih komunitas. Keputusan ini sangat bergantung pada potensi pertumbuhan ekonomi dan stabilitas, persaingan, iklim, politik, dan lain-lain.

Lokasi kampus sering pula disebut tempat kediaman kampus perguruan tinggi yaitu tempat dimana kampus perguruaan tinggi melakukan kegiatannya sehari-hari. Sedangkan istilah tempat kedudukan kampus dapat diartikan sebagai tempat kantor dan kegiatan perkuliahan mahasiswa sehari-hari.

Kedua hal diatas perlu untuk mendapat perhatian bagi kampus perguruan tinggi,sebab kesalahan dalam memilih suatu lokasi kampus akan mengakibatkan kerugian bagi kampus itu sendiri, seperti misalnya harus mengadakan penempatan kembali lokasi(relokation) dan kesulitan apabila akan mengadakan expansi. 
Dengan tajamnya persaingan serta banyaknya kampus perguruan tinggi sudah tidak mungkin dilakukan dengan cara coba-coba. Karena dengan cara itu kampus perguruan tinggi akan kalah dalam bersaing,disamping waktunya harus berpacu juga efisiensi dibidang biaya perlu mendapat perhatia, oleh karena itu pemilihan lokasi kampus ini harus dilakukan dan diputuskan melalui beberapa pertimbangan yang kongkrit dan lengkap.Hal itu bisa dijalankan dengan meninjau beberapa aspek perguruan tinggi.

Dasar pemikiran mendirikan kampus perguruan tinggi adalah memperoleh keuntungan untuk kelestarian hidup suatu perguruan tinggi dapat dipertahankan ,selain itu membuka kesempatan bagi lulusan SLTA untuk mendapatkan pendidikan yang lebih tinggi lagi yaitu jenjang diploma,strata satu (S1 ) strata dua (S2) dan strata tiga (S3). Juga membuka peluang kerja bagi tenaga kerja dibidang pendidikan serta dalam mencerdaskan bangsa dengan menyiapkan manusia yang terdidik yang siap kerja dan mendarma baktikan ilmunya di masyarakat demi negara dan bangsa.

Penentuan lokasi akan mempengaruhi tingkat keuntungan yang dapat dicapai kampus perguruan tinggi.Komponen keuntungan terdiri dari biaya modal (cost of capital),biaya operasional(operasional expensis) dan sumbersumber penerimaan (revenus).

Biaya modal yang dikeluarkan sebagian digunakan untuk mendirikan kampus baru maupun perluasan yang sudah ada. Umumnya biaya modal yang berjumlah sangat besar yang mencakup biaya gedung dan fasilitas operasional, dan besarnya biaya modal ini akan sangat dipengaruhi jarak dan harga yang berlaku pada lokasi tertentu yang diplih. Demikian juga biaya operasional yang mencakup upah/gaji/honor dosen,gaji karyawan ,biaya listrik, telepon, perawatan gedung dan peralatan serta biaya-biaya lainnya.

Jenis-jenis lokasi perguruan tinggi yang ada 4 jenis lokasi yaitu: 1.Lokasi kampus yang terkait dengan kebutuhan pemerintah daerah atau pangsa pasar; 2.Lokasi kampus yang berdasarkan sejarah; 3.Lokasi kampus yang ditetapkan pemerintah; 4.Lokasi kampus yang dipengaruhi oleh faktor-faktor ekonomi.
Faktor-faktor yang mempengaruhi pemilihan lokasi menurut Tjiptono(2007:92) menjelaskan bahwa pemilihan tempat lokasi memerlukan pertimbangan terhadap faktor-faktor berikut: a.Aksesibilitas,misalnya lokasi yang dilalui atau mudah terjangkau sarana transportasi umum; b.Visibilitas yaitu lokasi atau tempat yang dapat dilihat dengan jelas dari tepi jalan; c.Lalulintas (Traffic) dimana ada 2 hal yang perlu dipertimbangkan yaitu: 1.Banyaknya orang yang lalu lalang bisa memberikan peluang besar untuk terjadinya Impuls buying; 2.Kepadatan dan kemacetan lalu lintas yang bisa juga menjadi hambatan. d.Tempat parkir yang luas,nyaman dan aman;e.Expansi yaitu terjadinya tempat yang cukup luas untuk perluasan usaha dikemudian hari; f.Lingkungan ,yaitu daerah sekitar yang mendukungbiasa yang ditawarkan; g.Kompetisi yaitu lokasi pesaingh. Peraturan pemerintah,misalnya ketentuan yang melarang bengkel kendaraan bermotor terlalu berdekatan dengan daerah pemukiman.

\section{Pengertian Pelayanan}

Pelayanan dalam hal ini sangata erat kaitannya dengan hal pemberian kepuasan terhadap mahasiswa,pelayanan dengan mutu yang baik dapat memberikan kepuasan yang baik pula bagi mahasiswa agar merasa diperhatikan akan keberadaanya.

Menurut Moenir AS (2006:27) Pelayanan adalah kegiatan yang dilakukan oleh seseorang atau sekelompok orang dengan landasan faktor material melalui sistim prosedur dan dengan metode tertentu dalam rangka usaha memenuhi kepentingan orang lain sesuai haknya. Loina(2003:138), Pelayanan merupakan suatu proses keseluruhan dari pembentukan citra perusahaan, baik melalui media berita, membentuk budaya perusahaan kepada para pemimpin pemerintahan serta publik lainnya. Sedangkan Brata (2003 : 9), mengatakan suatu pelayanan akan terbentuk karena adanya proses pemberian layanan tertentu dari pihak penyedia layanan kepada pihak yang dilayani.

Ada beberapa faktor yang membuat pelayanan menjadi penting menurut Lena Ellitan dan Antan (2009:185) antara lain: (1) Industri jasa yang semakin bertumbuh seiring perkembangan bisnis global; (2) Persaingan antar sesama perusahaan yang semaik ketat,karena banyaknya pemain baru; (3) Tuntutan pelanggan yang semakin tinggi atas jasa yang 
diterimanya; (4) Pentingnya kualitas layanan bagi kelangsungan perusahaan itu sendiri.

Menurut Lewis dan Booms yang dikutip oleh Tjiptono dan Chandra (2005: 121) ada 2 faktor penting yang mempengaruhi kualitas jasa yaitu: (1) Jasa yang diharapkan (Expected services); (2) Jasa yang dirasakan (Perceved service)

Beberapa pengertian yang terkait dengan definisi kualitas jasa pelayanan yaitu: (1) Exellent adalah standar kinerja pelayanan yang diperoleh; (2) Customer adalah perorangan, kelompok, departemen atau perusahaan yang menerima, Membayar autput pelayanan; (3) Service adalah kegiatan utama atau pelengkap yang tidak secara langsung terlibat dalam proses pembuatan produk, tetapi lebih menekankan pada pelayanan transaksi antara pembeli dan penjual; (4) Levels aalah suatu pernyataan atas sistem yang digunakan untuk memonitor dan mengevaluasi; (5) Quality adalah sesuatu yang secara khusus dapat diraba atau tidak dapat diraba dari sifat yang dimiliki produk atau jasa; (6) Consistent adalah tidak memiliki variasi dan semua pelayanan beerjalan sesuai standar yang telah ditetapkan; (7) Delivery adalah memberikan pelayanan yang benar dengan cara yang benar dan dalam waktu yang tepat.

Adapun kriteria untuk mengukur kualitas pelayanan (Ariani,DW,2009 :182) yaitu: a) Pelayanan yang berkelas internasional berarti dapat memenuhi permintaan dan harapan konsumen tepat waktu pertama dan setiap saat; b) Memberikan jaminan kepuasan yang tinggi kepadakonsumen berdasarkan pada pertimbangan betapa berharganya uang yang mereka keluarkan; c) Memberikancitra yang baik kepada perusahaan ; d) Mampu mengatasi dan menguasai perubahan yang terjadi dan melakukan terobosan dalam memberikan pelayanan, tetapi mampu menjaga pengeluaran dibawah kembali.

Bentuk-bentuk pelayanan tidak terlepas dari tiga macam hal yaitu: 1) Pelayanan dengan cara lisan; 2) Pelayanan melalui tulisan; 3).Pelayanan melalui perbuatan.

\section{Pengertian Kepuasan Mahasiswa.}

Menurut Vincent Gaspersz (2005 : 17) tujuan utama dari konsumen dalam mengkonsumsi suatu produk yang dijual di pasar adalah untuk memaksimumkan kepuasan total. Sedangkan menurut Kotler (2002 :42 ) mendefinisikan kepuasan KonsumenPerasaan senang atau kecewa seseorangyang berasal dari perbandingan antara kesannya terhadap kinerja (atau hasil) suatu produk dan harapanharapannya.

Menurut Kotler (dalam Tjiptono 2005 :72 ) mengemukakan ada empat cara yang dapat dilakukan untuk mengukur kepuasan konsumen(mahasiswa):

1. Sistim keluhan dan saran

2. Survey kepuasan Konsumen. Pengukuran kepuasan konsumen melalui cara : a.Laporan Kepuasan Langsung (directly reportered satisfaction ); b.Berasal Ketidakpuasan (Derived Dissatisfaction ); c.Analisis masalah (Problem analisys); d.Analisis pentingnya kinerja (Importance performence analisys).

3. Pembelanja siluman (Ghost shopping);

4. Analisys konsumen yang hilang.

Menurut Gaspersz dalam (Nasution 2005 : 118) faktor-faktor yang mempengaruhi persepsi dan harapan pelanggan (mahasiswa)

1. Kebutuhan dan keinginan yang berkaitan dengan hal-hal yang dirasakan pelanggan ketika konsumen sedang mencoba melakukan transaksi dengan produsen;

2. Pengalaman masa lalu;

3. Pengalaman dari teman-teman; 4.Komunikasi melalui iklan dan penawaran juga mempengaruhi persepsi pelanggan.

\section{Pengertian Mahasiswa}

Mahasiswa adalah orang yang belajar di perguruan tinggi baik di Universitas,institut, sekolah tinggi,akademi. Lokasi kampus sangat menentukan untuk kemajuan kampus itu sendiri baik dari perencanaan ,pengelolaan,maupun pengembangannya. Sehingga lokasi kampus hendaklah strategis yang didukung oleh faktorfaktor lain baik internal seperti: dekat dengan akses jalan yang setiap saat bisa dilalui olerh kendaraan, bangunan yang memadai,sarana dan prasarana yang lengkap seperti: ruang perkuliahan, ruang laboratorium, ruang perpustakaan, ruang tunggu, ruang Musholla,WC, tempat parkir. Juga fakto internal yaitu: PLN,Telkom,kantin,jasa-jasa lain yang mendukung seperti: Fotocopi, percetakan, jasa keamanan dan faktor ekonomi. 
Faktor lain bagi perguruan tinggi selain lokasi kampus yaitu biaya perkuliahan, kemampuan dosen mengajar, karyawan yang terampil, adminstrasi yang rapih serta pola kepemimpinan.

Setelah dianalisa minat calon mahasiswa yang ingin kuliah di perguruan tinggi swasta yaitu: (1) Lokasi kampus; (2) Biaya perkuliahan; (3) Akreditasi Perguruan Tinggi; (4) Program perkuliahan; (5) Sarana dan prasarana yang memadai.

Maka jelaslah lokasi kampus yang strategis dan mudah terjangkau oleh transportasi umum, sarana dan prasarana yang lengkap memberikan kepuasan mahasiswa.

Selain itu pentingnya pelayanan kampus terhadap kepuasan mahasiswa perlu diperhatikan. Banyak hal yang perlu diperhatikan yaitu kecepatan karyawan dalam melayani mahasiswa seperti: memberikan informasi, surat menyurat, pembayaran, program perkuliahan yang dibutuhkan.

Mahasiswa merasa puas, jika lokasi kampus yang sangat strategis dengan sarana dan prasarana yang lengkap, didukung dengan pelayanan yang memuaskan serta faktor lain yaitu akriditasi perguruan tinggi, kualitas dosen, kegiatan intra dan extra kurikuler.

Pengaruh antara variabel bebas dengan variabel terikat yaitu sebagai berikut:

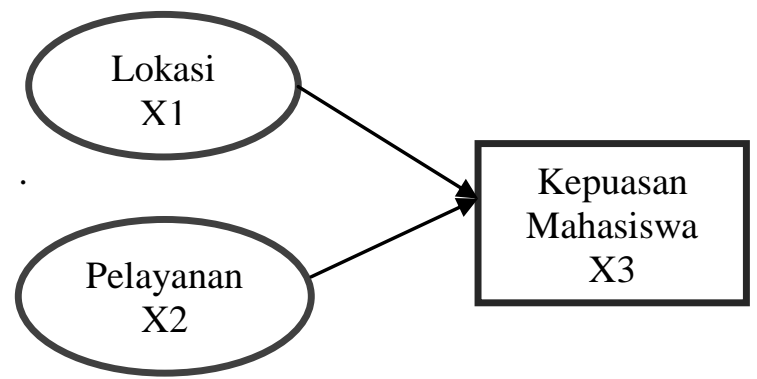

\section{METODE}

Metode yang digunakan adalah metode survey dengan pendekatan pengaruh dan menggunakan data dari kuisioner yang dibagikan kepada mahasiswa STMIK Pranata Indonesia Bekasi secara random sampling pada tahun 2014 dan diambil sampel sebanyak 30 orang,Adapun untuk mengukur hasil jawaban kuisioner menggunakan skala likert dengan setiap jawaban respinden diberi bobot jumlahnya masing-masing: a. Sangat setiap,skor 5, b.setuju skor 4, c.Kurang setuju skor 3,dan d. Tidak setuju skor 2, e.sangat tidak setuju skor 1 .

Teknik analisis data terdiri dari dua bagian yaitu analisa deskriptip dan analisa statistik. Analisa deskriptif digunakan untuk menjelaskan pengaruh lokasi dan pelayanan terhadap kepuasan mahasiswa di STMIK Pranata Indonesia Bekasi.

\section{HASIL DAN PEMBAHASAN PENELITIAN}

Penelitian ini menggukan metode survey dengan pengambilan data dari hasil wawancara, pengajuan quisioner kepada mahasiswa STIMIK Pranata Indonesia.

Kepuasan mahasiswa merupakan variabel terikat dan pada penelitian ini merupakan variabel yang diutamakan. Kepuasan mahasiswa dipengaruhi oleh lokasi kampus dan pelayanan. Kepuasan mahasiswa adalah variabel terikat sebagai simbol X1 kemudian dicari pasangannya dengan lokasi kampus sebagai variabel bebas dengan simbol X2 dan Pelayanan sebagai variabel bebas dengan simbol X3

Adapun hasilnya dengan data sebagai berikut: $\sum X 1=1286, \quad \sum X 2=1128, \quad \sum X 3=1060, \sum X 1^{2}=$ 55286, $\quad \sum X 2^{2}=44006, \quad \sum X 3^{2}=38128, \quad \sum X 1 X 2$ $=47804, \quad \sum X 1 X 3=44063, \quad \sum X 2 X 3=39863$, $\mathrm{a}=-87,7, \quad \mathrm{~b} 2=1,5, \quad \mathrm{~b} 3=2,1, \quad \mathrm{JK} \quad \operatorname{Reg}=$ $94224,3, \mathrm{JK}(\mathrm{S})=71155,3$.

$\mathrm{F}$ hitung $=17,87, \mathrm{~F}$ (tabel) $=(0,05,2,27)=$ 3,58 dengan nilai $\mathrm{F}=17,87>3,58$ dapat diambil kesimpulan regresi linier multiple X1 terdapat X2 dan X3 adalah berarti, dengan kata lain $\quad \mathrm{X} 1=-87,7+1,5 \mathrm{X} 2+2,1$ $\mathrm{X} 3$, secara berarti atau signifikan dapat digunakan untuk meramal regresi multiple ,populasi yang diteliti.

$\mathrm{S} 1(2,3)^{2}=136,2, \mathrm{~S} 1(2,3)=11,67, \mathrm{r} 2(3)=0,97$, $\mathrm{r} 2(3)^{2}=0,94, \mathrm{Sb} 2=106,1, \mathrm{Sb} 3=145,87$.

Setelah diuji tingkat keberartian persamaan regresi $\mathrm{X} 1=-87,7+1,5 \mathrm{X} 2+2,1 \mathrm{X} 3$, untuk regresi populasi, maka dapatlah dilakukan uji hipotesis:

$\mathrm{H} 0: \mathrm{B} 2=0, \mathrm{H} 0: \mathrm{B} 3=0 \quad \mathrm{Ha}: \mathrm{B} 2 \neq 0, \mathrm{Ha}$ $: \mathrm{B} 3 \neq 0$ dengan taraf signifikannya $=0,05 \mathrm{~b} 2-$ B3 Statistik uji $\mathrm{t}=$------ , dengan $\mathrm{df}=30-$ $2-1=27$, hasilnya 0,01 


\section{$\mathrm{Sb} 2$}

Uji secara 1 arah, menurut tabel $\mathrm{t}(0,05,27)=$ 1,314 , terbukti $\mathrm{t}=0,01 \rightarrow 0,01<1,314$, maka $\mathrm{H} 0: \mathrm{B} 2=0$ diterima atau Ha ditolak dan b3 B3 Uji statistik $\mathrm{t}=$--------, hasilnya $=0,01$

\section{Sb3}

Terbukti $\mathrm{H} 0$ : $\mathrm{B} 3=0$ diterima dan $\mathrm{Ha}$ ditolak. Dugaan parameter B2 dengan derajat kepercayaan $95 \%$

$\mathrm{P}\{(1,5-106,1)(1,314)<\mathrm{B} 2<1,5+(106,1$ ) $(1,314)=0,95$. $\mathrm{P}(-137,4<\mathrm{B} 2<140,9)=0,95$ Nilai keyakinan bawah untuk parameter b2 adalah lebih kecil -137,4 dan nilai keyakinan atas kurang dari 140,9. $\mathrm{P}(2,1-145,87)(1,314$ )$<\mathrm{B} 3<(2,1+(145.87)(1,314) \mathrm{n}=0,95 . \mathrm{P}$ 188,9 < B3 < 193,8 ), nilai keyakinan bawah untuk parameter b3 adalah lebih kecil dari 188, 9 dan nilai keyakinan atas kurang dari 193,8

\section{SIMPULAN}

Langkah pertama dilakukan perhitungan besarnya a, b2, b3.Ternyata $\mathrm{a}=-87,7, \mathrm{~b} 2=$ 1,5 , dan $\mathrm{b} 3=2,1$, maka persamaan regresinya yaitu $\mathrm{X} 1=-87,7+1,5 \mathrm{X} 2+2,1 \mathrm{X} 3$. Secara deskriptip diketahui dampak perubahan X2 terhadap X1 adalah sama besarnya dengan X3 terhadap X1 yaitu $+0,01$ artinya lokasi kampus sama besarnya dengan pelayanan terhadap kepuasan mahasiswa. Jadi pengaruh keduanya yaitu lokasi kampus dan pelayanan terhadap kepuasan mahasiswa tidak berpengaruh. Besarnya b2 dan b3 itu diartikan bahwa lokasi kampus sama dengan pelayanan terhadap kepuasan mahasiswa. Untuk menggambarkan lebih jelas dampak kedua variabel (X2 dan X3) terhadap X1 dapat dilihat secara geometris sebagai berikut:

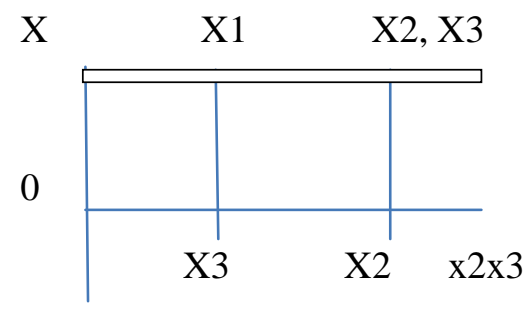

$\mathrm{X} 1 / \mathrm{X} 3=\mathrm{X} 1 / \mathrm{X} 2$ atau $\mathrm{Tg} \mathrm{X} 3=\mathrm{Tg} \mathrm{X} 2$

Jadi pada diagram diatas bahwa walaupun perubahan X3 yang kecil tidak dapat memberikan dampak yang besar kepada X1 ,begitupun X2 terhadap X1.

Hal ini terbukti dari angka $\mathrm{t}$ hitung distribusi normal lokasi kampus sama dengan $\mathrm{t}$ hitung pelayanan terhadap mahasiswa yaitu $=$ $0,01,0,01<1,314$.Artinya lokasi kampus dan pelayanan tidak ada pengaruh terhadap kepuasan mahasiswa.

\section{SARAN}

1. Kampus Perguruan Tinggi dalam menentukan lokasi hendaklah yang strategis,dekat dengan jalan yang setiap saat dilalui kendaraan umum,adanya sarana dan prasarana yang memadai seperti: perpustakaan,laboratorium, mushollah,tempa t parkir,WC dan pos keamanan.

2. Untuk tercapainya kepuasan mahasiswa di perguruan tinggi,maka gaya kepemimpinan baik rektor/Ketua, Dekan, Prodi, Staff harus demokratis, harmonis, dan sosiologis.

3. Jika ada permasalahan tentang kepuasan mahasiswa hendaklah diselesaikan dengan baik dan demokratis.

4. Ciptakan hubungan yang harmonis dan kondusif antara pejabat,staff danmahasisw

\section{DAFTAR RUJUKAN}

Kotler Philip,Keller Kevin Lane,2009, Manajemen Pemasaran Jilid 1, ,Indeks,Jakarta

Sutojo Siswanto,2008, Manajemen Pemasaran untuk Eksekutif Noin Pemasaran, Erlangga, Jakarta

Kotler Philip, 2000, Manajemen Pemasaran jilid 2, Bumi Aksara, Jakarta

Sumaryoto, 2008, Pedoman Penulisan Skripsi/Tugas akhir,Unindra,Jakarta

Kucoro Siswanto, 2008, Manajemen Pemasaran untuk Eksekutif,Erlangga, Jakarta.

Moenir,AS, 2006, Manajemen Pelayanan umum di Indonesia, PT Bumi Aksara, Bandung

Brata,2003,Dasar-dasar Pelayanan Prima,Erlangga, Jakarta. 
uwandi,Hendy

Irawan,2004,Kepuasan

Pelayanan Jasa,Erlangga,Jakarta

Ariani,DW, 2004, Pengendalian Kulitas

Statistik Pendekatan dan Manajemen

Kualitas, ANDI, Jogyakarta.
Gaspersz,Vincent,Dr, 2005, Metode analisis untuk peningkatan Kualitas, Gramedia Pustaka Utama, Jakarta.

Anatan, Lina dan Lena Ellitan, 2007, Manajemen Sumber Daya manusia dalam Bisnis, Alfabeta, Bandung 